\title{
NOTE
}

\section{Eppur si muove: many water column bacteria are motile}

\author{
Tom Fenchel* \\ Marine Biological Laboratory (University of Copenhagen), Strandpromenaden 5, 3000 Helsingør, Denmark
}

\begin{abstract}
Models of chemosensory behaviour and microscale patchiness in the water column often assume that most or all suspended bacteria are motile. Yet direct observations on fresh seawater samples seem to indicate that only a few percent of suspended bacteria swim. Consequently, most experimental studies on the role of bacterial chemotaxis in the water column depend on pure strains of bacteria or on incubations enriched with organic substrates. Here it is shown that a large fraction (typically $>20 \%$ ) of the bacteria (in terms of direct counts) are, in fact, motile and show chemosensory behaviour. The discrepancy is due to the tendency of motile bacteria to attach rapidly to solid surfaces; in microscope preparations that are suited for observation of $\mu \mathrm{m}$-sized particles most motile cells will become attached within a few seconds.
\end{abstract}

KEY WORDS: Bacterial motility $\cdot$ Chemotaxis · Plankton bacteria

Resale or republication not permitted without written consent of the publisher

There has recently been much interest in microscale heterogeneity in the water column, including phenomena such as the formation and colonisation of colloid aggregates and the clustering of bacteria around point sources of dissolved organics such as algal cells or lysing microbes. Theoretical approaches (e.g., Azam \& Ammerman 1984, Mitchell et al. 1985, Jackson 1987 , 1989, Bowen et al. 1993, Kepkay 1994, Blackburn et al. 1997, 1998, Blackburn \& Fenchel 1999) all implicitly assumed that the majority of bacteria show motile chemosensory behaviour. Experimental approaches, on the other hand, have relied on pure cultures (e.g., Malmcrona-Friberg et al. 1990) or on seawater enriched with organic substrates, seemingly resulting in a higher percentage of motile cells (e.g., Bell \& Mitchell 1972, Mitchell et al. 1995, Blackburn et al. 1998, Blackburn \& Fenchel 1999).

Usually very few bacteria appear motile in freshly collected seawater samples. Mitchell et al. (1995)

\footnotetext{
*E-mail: tfenchel@zi.ku.dk
}

approached this paradox systematically. Their direct observations on fresh seawater samples always revealed less than $10 \%$ motile cells. Adding an organic substrate to seawater samples yielded a larger fraction of motile cells after a lag time of 7 to $12 \mathrm{~h}$ and it peaked after 15 to $30 \mathrm{~h}$. The authors concluded that planktonic bacteria normally have limited energy to swim and that the long lag was due to induction of motility rather than to differential growth of motile versus non-motile strains. If this is so, then the adaptive nature of motile chemosensory behaviour in the water column would appear less obvious and it would preclude, e.g., clustering around ephemeral point sources of substrates. The present study shows that the apparent scarcity of motile cells observed microscopically is often an artefact because bacteria adhere rapidly to solid surfaces. While direct enumeration of the percentage of motile cells seems almost impossible in practice, experiments herein exploit the sorption of motile cells to surfaces in a non-convective suspension in 3 different ways in order to estimate the role of motile cells and chemosensory behaviour in seawater.

Material and methods. Seawater samples were collected from the surface of the Sound off Helsingør North Harbour during summer and autumn 2000. Additional samples derived from $25 \mathrm{~m}$ depth $10 \mathrm{~m}$ below the pycnocline and from the running seawater system of the Marine Biological Laboratory deriving from $30 \mathrm{~m}$ depth. All experiments were initiated within $0.5 \mathrm{~h}$ after collection.

Adsorption to cover glasses: A rubber O-ring was attached with vaseline to a microscope slide. Seawater was applied with a pipette inside the O-ring and covered with a cover slip avoiding air bubbles. The height of the chamber was $2 \mathrm{~mm}$, its internal surface $4.48 \mathrm{~cm}^{2}$, and its volume $0.353 \mathrm{~cm}^{3}$. Focusing on the underside of the cover slip with a $20 \times$ objective and using dark field illumination, it was possible to observe swimming cells attach to the cover slip and to count the number of attached cells at short time intervals. 
Migration into hypodermic needles: Hypodermic needles (length $1.8 \mathrm{~cm}$, internal diameter $200 \mu \mathrm{m}$ ) filled with either sterile seawater or sterile seawater with an attractant $(0.1 \%$ peptone or $50 \mathrm{mM}$ glycine $+50 \mathrm{mM}$ glucose) were mounted on syringes. The needle tips were immersed in a seawater sample. At intervals the syringes were removed and $0.1 \mathrm{~cm}^{3} 2 \%$ formalin solution was drawn into the syringe via the needle followed by a DAPI solution. The needle was then removed and the content of the syringe was filtered through a $13 \mathrm{~mm}$ black $0.2 \mu \mathrm{m}$ filter and bacteria were counted using fluorescence microscopy.

Colonisation of agar spheres: Relatively uniform agar spheres were made by dropping warm, sterile $2 \%$ seawater agar from a pipette into paraffin oil overlying sterile seawater in a beaker. Some spheres were also prepared with $0.1 \%$ peptone as chemo-attractant. The diameter was a function of the aperture of the pipette; most spheres used had a diameter of 2 or $2.5 \mathrm{~mm}$ (SD about $15 \%$ ). The agar spheres were transfixed on glass needles and suspended in seawater samples. They were removed at intervals, placed on a microscopic slide, and drops of formalin and DAPI solutions were added $_{i}$ after application of a cover slip the number of bacterial cells per unit surface area of the spheres could be counted.

Comparison with a cultured bacterium: A motile, approximately $2 \mu \mathrm{m}$ long unidentified rod was isolated on nutrient agar. Suspensions of $100 \%$ motile cells of this organism were also submitted to the described experiments as a comparison with natural seawater samples. The motility patterns of the isolated strain (swimming speeds, frequency of reorientation in swimming direction) were determined from video recordings, as described in Blackburn et al. (1998).

Interpretation of results: Underlying all these experiments is the assumption that in the absence of convective flow, non-motile cells will be practically unable to attach to surfaces within an appreciable time because the motility caused by Brownian motion is about 4 orders of magnitude lower than that of swimming bacteria (Berg 1983). Cells that adhere in the experiments thus represent a minimum estimate of motile cells. This is because cells have a differential tendency to adhere to different types of surfaces. Also, at least initially, sorption to surfaces is reversible (e.g., Lawrence et al. 1987) and so with a finite pool of cells such as in the Oring chambers an equilibrium number of adhering cells will be approached that represents only a fraction of the swimming cells. There is also evidence to show that motility and especially the presence of polar flagella enhances the ability to attach to surfaces (Kogure et al. 1998).

Results and discussion. A typical result from an Oring chamber is seen in Fig. 1a, and Fig. 1b summarises

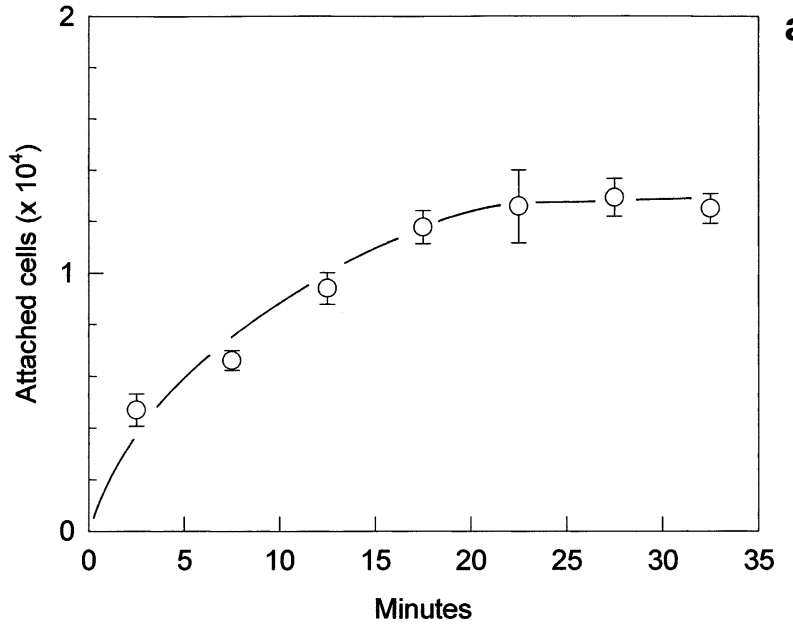

a

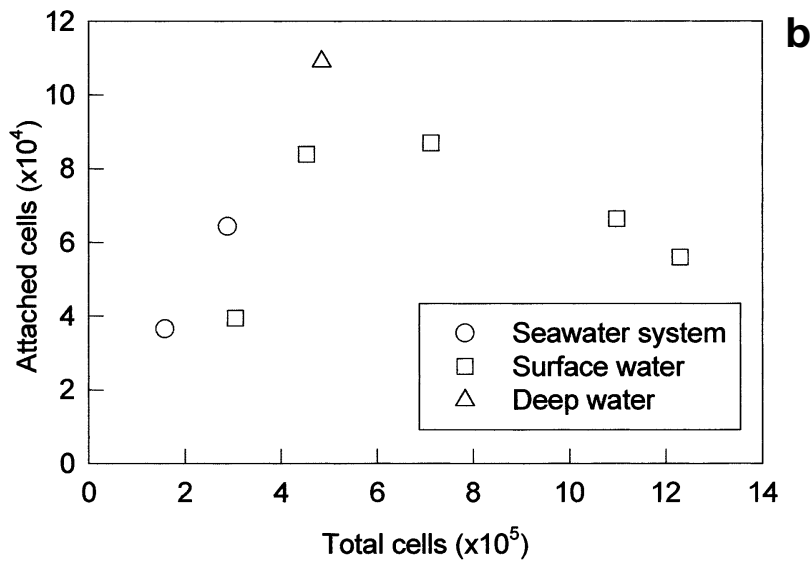

Fig. 1. Attachment of bacteria in the O-ring chamber. (a) Surface water; total number of bacteria in the chamber: $3.05 \times 10^{5}$. Several fields $(400 \times 400 \mu \mathrm{m})$ counted in $2.5 \mathrm{~min}$ intervals attached cells $\mathrm{cm}^{-2}$ surface; bars, SE of counts. (b) Number of total attached cells after 30 min incubations for 7 seawater samples and as a function of total cell number in chamber. Data show considerable variation among different water samples

results from 7 such experiments. As in the case of the other experiments described below, there was considerable variation among samples collected at different times. With 2 exceptions, however, about $20 \%$ of the bacteria within the chamber had attached to surfaces within 20 to $25 \mathrm{~min}$. Similar experiments with the cultured strain (100\% motile) yielded $75 \%$ equilibrium attachment to surfaces; provided that the mixed assemblage of bacteria in the seawater samples behaved similarly, this would suggest that about $30 \%$ of the bacteria in the natural seawater samples were swimming.

The mean time for attachment was 4.0 min (SD 1.75) for the natural assemblages and $2.3 \mathrm{~min}$ (SD 0.24) for the cultured bacterium. These figures can be used to estimate the motility of the organisms. Bacterial motility 
can be approximated as a diffusion coefficient given as $D=v^{2} \tau / 3$ where $v$ is swimming velocity and $\tau$ is the mean time intervals between tumbles (Berg 1983). The mean time for the capture of particles performing random walk in a suspension between 2 parallel, absorbing walls is given by $T=a^{2} / 8 D$, where $a$ is the distance between the walls (Berg 1983). For the natural bacterial assemblage this yields $D=2.3 \times 10^{-5} \mathrm{~cm}^{2} \mathrm{~s}^{-1}$, which is consistent with estimates for typical swimming bacteria (Mitchell et al. 1995). For the cultured bacterial strain the value was similar $\left(3.6 \times 10^{-5} \mathrm{~cm}^{2} \mathrm{~s}^{-1}\right)$; its 'diffusivity'
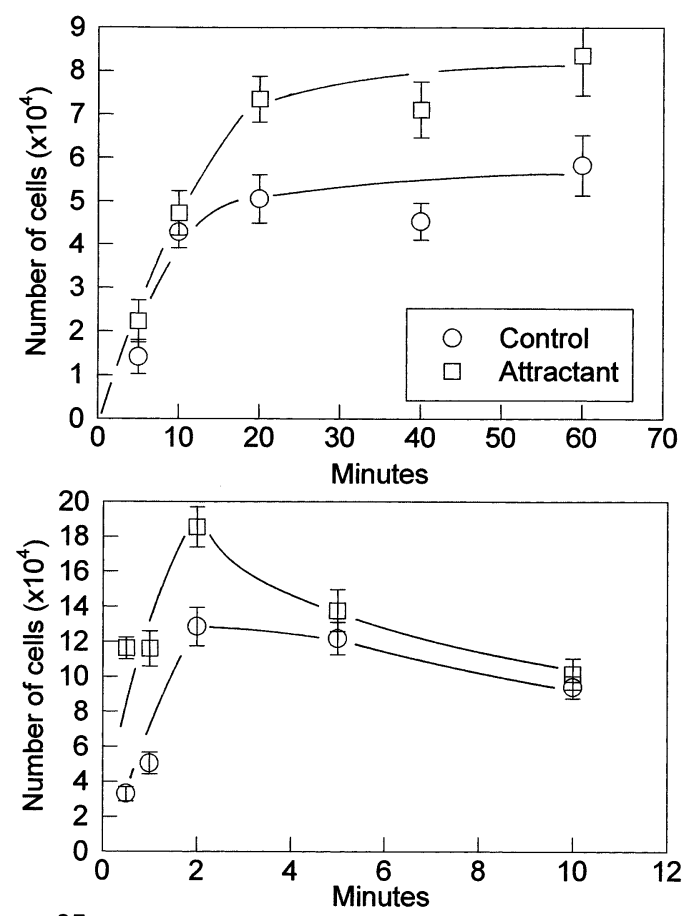

b

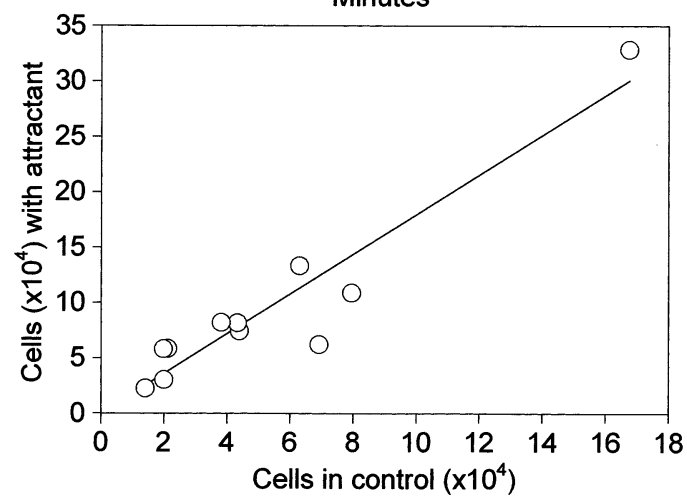

Fig. 2. Migration into hypodermic needles. (a) Surface water collected August 28, 2000; total bacterial count: $3.22 \times 10^{6}$ cells $\mathrm{cm}^{-3}$; attractant: glycine+glucose. (b) Surface water; cell concentration: $1.58 \times 10^{6} \mathrm{~cm}^{-3}$; attractant: peptone. Bars, SE of counts. (c) Relations between number of bacteria having entered hypodermic needles with and without attractants after 5 min incubation for 7 samples including surface and deep water and 2 water samples from a seawater aquarium system was also calculated directly from recorded swimming tracks (not shown) as $4.5 \times 10^{-5} \mathrm{~cm}^{2} \mathrm{~s}^{-1}$. The fact that the mean time of sorption in this sort of chamber is inversely proportional to the squared distance between the absorbing walls shows that absorption of motile bacteria is very fast in a normal microscope preparation. Mitchell et al. (1995) used pieces of cover slips $(0.17 \mathrm{~mm})$ to separate the slide and cover slip; on the basis of the present results the expected mean time for adherence of bacteria would then be about $1.7 \mathrm{~s}$, thus explaining why only a few motile cells were observed.

Fig. 2 shows the migration into and attachment inside submerged hypodermic needles. The volume of the needles was $5.6 \times 10^{-4} \mathrm{~cm}^{3}$ so that $10^{5}$ bacteria correspond to a density of about $1.8 \times 10^{8}$ cells cm $\mathrm{cm}^{-3}$ (corresponding to a 100 -fold increase relative to the ambient concentration); such numbers were reached after between 2 and $20 \mathrm{~min}$. When cell numbers inside the needles exceeded $10^{5}$ cells, numbers tended to decrease again later to around $10^{5}$. The reason for this is not clear. It is possible that the available $\mathrm{O}_{2}$ becomes exhausted at high densities. After $2 \mathrm{~min}$ the bacteria could not possibly have migrated longer than 0.5 to $1 \mathrm{~cm}$ within the needles and mainly attached within this distance and so the actual bacterial density close to the opening of the syringes could have been much higher.

These experiments are not well suited for estimating the fraction of motile bacteria since the net migration into the needles seems to be limited by mechanisms other than motility and also because the geometry of the points of the hypodermic needles is somewhat complex. The experiments do, however, demonstrate the effect of chemosensory motile behaviour: when the needles were filled with an attractant solution the initial migration of bacteria into the needles was about 2 times higher than when sterile seawater was applied (Fig. 2c).

Agar spheres suspended in stagnant seawater were also colonised rapidly (Fig. 3). The number of cells that became attached to the spheres decreased with time to reach a relatively stable rate. In 3 cases, using $2.5 \mathrm{~mm}$ spheres and an ambient bacterial concentration of about $2.5 \times 10^{6} \mathrm{~cm}^{-3}$ this 'steady state' level was 10 to 20 cells $\mathrm{min}^{-1}$. Again using diffusion approximations, the flux to a spherical collector is given as $F=4 \pi C R D$ where $C$ is concentration, $R$ is the radius of the spheres, and $D$ is the diffusion coefficient (Berg 1983). Taking $F$ as $0.15 \mathrm{~s}^{-1}, R=0.125 \mathrm{~cm}$, and $D=2 \times 10^{-5} \mathrm{~cm}^{2} \mathrm{~s}^{-1}$, then $C=4.8 \times 10^{5} \mathrm{~cm}^{-3}$, corresponding to about $20 \%$ motile cells. Since not all cells adhere permanently and some may have been lost while recovering the agar spheres, this may represent a minimum estimate. Agar spheres amended with $0.1 \%$ peptone as a bacterial attractant increased the initial colonisation rate by a factor of 1.5 to 2 (Fig. 3a). When suspended agar spheres were 

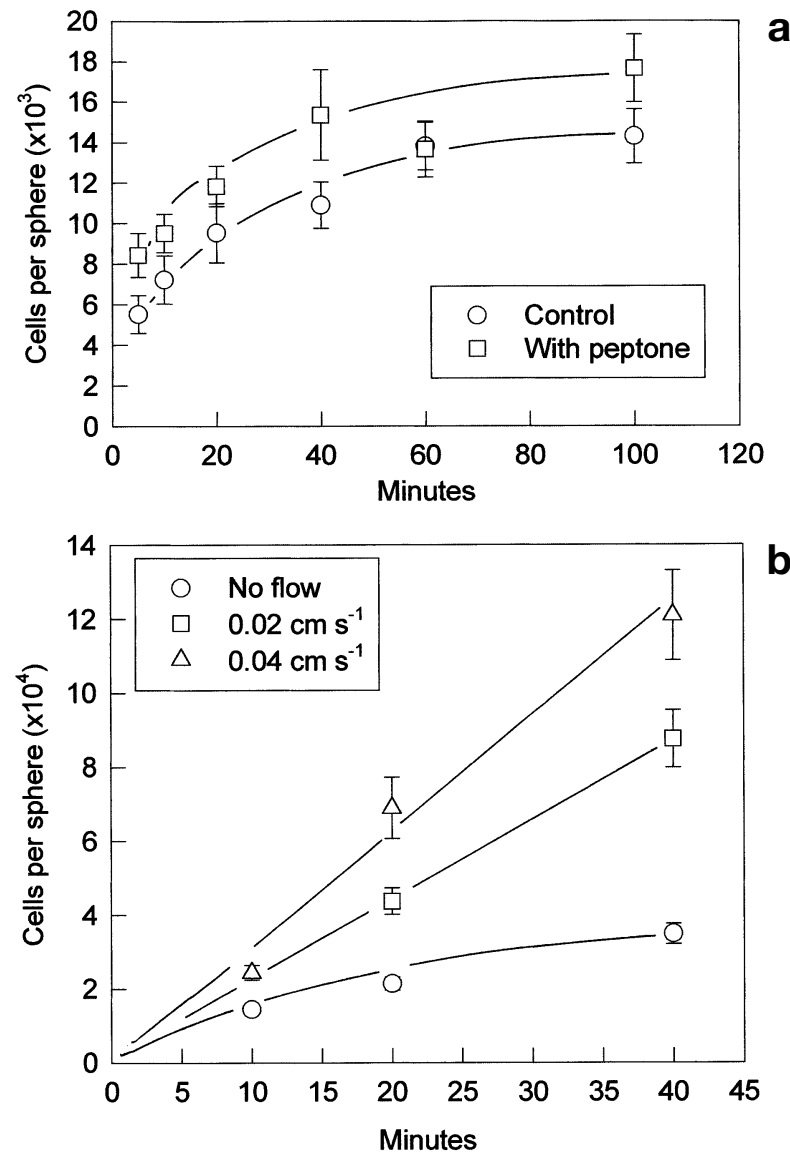

Fig. 3. Colonisation of agar spheres. (a) Colonisation of $2.5 \mathrm{~mm}$ spheres with and without attractant; ambient bacterial concentration: $2.50 \times 10^{6} \mathrm{~cm}^{-3}$; bars, SE of counts. (b) Colonisation by cultured bacterial strain on $2.2 \mathrm{~mm}$ spheres in stagnant water and exposed to 2 flow velocities; ambient bacterial concentrations: $1.47 \times 10^{6} \mathrm{~cm}^{-3}$

exposed to laminar water flow, colonisation was faster and took place at a constant rate (Fig. 2c); this probably applies to colonisation of, e.g., sinking marine snow particles.

The present results derive from more or less indirect evidence and estimates of the percentage of motile cells cannot be considered as being very accurate; but it is a robust conclusion that a fairly large fraction of plankton bacteria is motile and that they can respond immediately to chemical cues in the environment. The time limit for the utilisation of ephemeral point sources of dissolved organic matter (e.g., lysing cells) is at the most 5 to 10 min (Blackburn \& Fenchel 1999) and the present study suggests that there is a large pool of bacteria in natural seawater that is capable of this.

When estimates of motile cells are compared to total counts it should also be recalled that they may include dead or metabolically inactive cells although it is still not known to what extent this is so. Zweifel \& Hag- ström (1995) showed that a sizable fraction of cells may be ghosts devoid of a chromosome even though they stain with commonly used fluorochromes (such as DAPI). It is also evident that metabolically inactive and starving cells may constitute a substantial fraction of the bacterial biota (for discussion see Choi et al. 1999). It is therefore possible that most viable and metabolically active cells are motile.

When live samples have been observed with low magnification dark field microscopy in order to assess the frequency of motile cells, it is an additional problem that not only dead or metabolically inactive cells but all sufficiently refractive $\mu \mathrm{m}$-sized particles are likely to be counted as non-motile bacteria. The experiments of Mitchell et al. (1995) showing an increase in the fraction of motile cells several hours to days after amendment with organic substrates therefore most likely reflect population growth of metabolically active cells on the background of a constant number of nonviable cells and other particles in the water.

Acknowledgements. The study was supported through a grant from the Danish Natural Science Research Council. I am grateful to Ms Marina Madsen for technical assistance.

\section{LITERATURE CITED}

Azam F, Ammerman JW (1984) Cycling of organic matter by bacterioplankton in pelagic marine ecosystems: microenvironmental considerations. In: Fasham MJR (ed) Flows of energy and material in marine ecosystems. Plenum Press, New York, p 345-360

Bell W, Mitchell R (1972) Chemotactic and growth responses of marine bacteria to algal extracellular products. Biol Bull 143:265-277

Berg HC (1983) Random walks in biology. Princeton University Press, Princeton, NJ

Blackburn N, Fenchel T (1999) Influence of bacteria, diffusion and shear on micro-scale nutrient patches, and implications for bacterial chemotaxis. Mar Ecol Prog Ser 189:1-7

Blackburn N, Azam F, Hagström Å (1997) Spatially explicit simulations of a microbial food web. Limnol Oceanogr 42: 613-622

Blackburn N, Fenchel T, Mitchell J (1998) Microscale nutrient patches in planktonic habitats shown by chemotactic bacteria. Science 282:2254-2256

Bowen JD, Stolzwenbach KD, Chisholm SW (1993) Simulating bacterial clustering around phytoplankton cells in a turbulent ocean. Limnol Oceanogr 38:36-51

Choi JW, Sherr BF, Sherr EB (1999) Dead or alive? A large fraction of ETS-inactive marine bacterioplankton cells, as assessed by reduction of CTC, can become ETS-active with incubation and substrate addition. Aquat Microb Ecol 18:105-115

Jackson GA (1987) Simulating chemosensory responses of marine microorganisms. Limnol Oceanogr 32:1253-1266

Jackson GA (1989) Simulation of bacterial attraction and adhesion to falling particles in an aquatic environment. Limnol Oceanogr 34:514-530

Kepkay PE (1994) Particle aggregation and the biological reactivity of colloids. Mar Ecol Prog Ser 109:293-304 
Kogure K, Ikemoto E, Morisaki H (1998) Attachment of Vibrio alginolyticus to glass surfaces is dependent on swimming speed. J Bacteriol 180:932-937

Lawrence JR, Delaquis PJ, Korber DR, Caldwell DE (1987) Behavior of Pseudomonas fluorescens within the hydrodynamic boundary layers of surface microenvironments. Microb Ecol 14:1-14

Malmcrona-Friberg K, Goodman A, Kjelleberg S (1990) Chemotactic responses of marine Vibrio sp. Strain S14 (CCUG 15956) to low-molecular-weight substances under starvation and recovery conditions. Appl Environ

Editorial responsibility: Fereidoun Rassoulzadegan, Villefranche-sur-Mer, France
Microbiol 56:3699-3704

Mitchell JG, Okubo A, Fuhrmann JA (1985) Microzones surrounding phytoplankton form the basis for a stratified marine ecosystem. Nature 316:58-59

Mitchell JG, Pearson L, Bonazinga A, Dillon S, Khouri H, Paxinos R (1995) Long lag times and high velocities in the motility of natural assemblages of marine bacteria. Appl Environ Microbiol 61:877-882

Zweifel UL, Hagström Å (1995) Total counts of marine bacteria include a large fraction of non-nucleotid 'ghosts'. Appl Environ Microbiol 61:2180-2185

Submitted: January 11, 2001; Accepted: March 12, 2001 Proofs received from author(s): April 24, 2001 